Michael Bonello, MRCP

Anu Jacob, FRCP, DM

Mark A. Ellul, MRCP

Erandi Barker, MRCP

Robert Parker, FRCP, FFICM

Samantha Jefferson, MRCP, PhD

Sundus Alusi, FRCP, MD

Neurol Neuroimmunol

Neuroinflamm

2017;4:e383; doi: 10.1212/

NXI.0000000000000383

Supplemental data at Neurology.org/nn

\section{IgLON5 DISEASE RESPONSIVE TO IMMUNOTHERAPY \\ OPEN}

A 45-year-old man was seen with a history of confusion and disorientation for 1 year, during which time he was unable to identify relatives. He was unable to cope at his work as a plasterer, noticed neck pain, dysphagia, and unexplained weight gain. His family reported that his sleep pattern had changed, describing his sleep as disturbed with episodes consistent with stridor, myoclonus (the video at Neurology.org/nn), and semipurposeful movements.

At his initial examination, he appeared mildly confused with a depressed affect. He was obese (body mass index of $33 \mathrm{~kg} / \mathrm{m}^{2}$ ) and was noted to be centrally cyanosed (figure e-1). He had mild gait ataxia, bulbar dysarthria, and dysphagia. The rest of his examination was normal. He was found to have established ventilatory failure and sleep-disordered breathing. EEG demonstrated a baseline of theta waves with $\alpha$ rhythm intermixed. CSF analysis was abnormal, suggesting inflammation (table). MRI of the head and neck was normal. Inpatient polysomnography with video was extremely limited by the patient's limited sleep duration and nocturnal behavioral problems. The awake period evaluation revealed intermittent runs of theta wave activity suggesting an increased homeostatic sleep drive. Frequent spontaneous desaturations were noted, some of which were central in nature. The sleep period evaluation demonstrated an increased sleep onset latency and reduction in nonREM stage 2 sleep and a complete absence of REM sleep (figure e-2). His apnea-hypopnea index was 25 , confirming moderate obstructive sleep apnea. Nocturnal noninvasive ventilation was issued for long-term use, but initial adherence was poor.

The patient was initially treated with prednisolone and immunoglobulins. This was associated with improvement in behavior mirrored by improvement in CSF parameters, and he became well enough to be discharged home. However, he was admitted 6 weeks later with aspiration pneumonia and ventilatory failure requiring intensive care support. His sleep disorder was still prominent clinically and required further treatment with plasmapheresis followed by another course of IV immunoglobulins, which led to a rapid improvement over a few weeks. A repeat CSF analysis confirmed raised protein suggestive of persistent inflammation, and further IV-pulsed cyclophosphamide was given. After 2 pulses, his behavior normalized and sleep pattern improved with return of dreams, and resolution of neck pain and dysphagia.

Serum antibodies to IgLON5 returned positive using indirect immunofluorescence (Euroimmun). CSF testing for the antibody was also positive (figure e-3). The patient continued treatment with cyclophosphamide, and he has received 8 pulses so far. His human leukocyte antigen (HLA) genotyping confirmed HLA-DQB1*05:01 and HLADRB1*10:01 alleles.

At his last review (2 years from the onset of his initial symptoms), he continues to improve. $\mathrm{He}$ exhibited no evidence of cognitive impairment or abnormal behavior, and there were no involuntary movements. His gait remains mildly ataxic. Noninvasive ventilation has been established with improvement in his arterial blood gases. His spouse reports better sleep patterns.

Discussion. A recent report suggested treatment with immunotherapy for a patient with IgLON5 encephalitis. ${ }^{1}$ Here, we provide further evidence of an IgLON5-associated disorder that has shown sustained response to immunotherapy.

IgLON5 antibody-associated encephalopathy was first described in 2014. ${ }^{2}$ Sleep disturbance was characteristic in all these patients' presentations. Other features including gait ataxia, bulbar dysarthria, and dysphagia ${ }^{2}$ were also present. Movement disorders associated with IgLON5 syndrome, including orofacial and limb chorea, ${ }^{1}$ dystonia, hypomimia, bradykinesia, and myoclonus. ${ }^{3}$ Cognitive decline featuring impaired executive function, visuospatial dysfunction, and episodic memory loss has been reported. ${ }^{4}$ Brain imaging is typically normal. The youngest patient reported in the literature was 52 years old. ${ }^{2}$

The physiologic role of IgLON5 is unknown, but other members of the IgLON family are involved in synaptic and neuronal formation during brain development. ${ }^{5}$ Antibodies to IgLON5 have been originally linked with a tauopathy when they were detected in 8 


\section{Table CSF analysis confirmed a pleocytosis (100\% lymphocytes) with raised protein suggestive of CSF inflammation}

\section{December 2015 January 2016 March 2016 July 2016}

$\begin{array}{lllll}\text { Red blood cell count, per } \mathrm{mm}^{3} & 0 & 1,920 & 3 & 4 \\ \text { White blood cell count, per } \mathrm{mm}^{3} & 14 & 3 & 1 & 1 \\ \text { Total protein, g/L } & 0.84 & 0.77 & 0.82 & 0.84 \\ \text { CSF glucose, mmol/L } & 4.0 & 6.5 & 6.6 & 6.2 \\ \text { Plasma glucose, mmol/L } & 3.5 & 5.8 & 6.9 & 6.4 \\ \text { Oligoclonal bands } & \text { Negative } & \text { Negative } & \text { Negative } & \text { Negative }\end{array}$

patients with a similar clinical presentation. ${ }^{2}$ IgLON5-associated disorder provides an interesting link between neurodegeneration and autoimmunity. All patients who were HLA genotyped had the same alleles: HLA-DQB1*05:01 and HLA-DRB1*10:01. ${ }^{2}$ Autopsy on 6 patients revealed hyperphosphorylated tau protein deposited in the hypothalamus, prehypothalamic region, the tegmentum, and the upper cervical cord. ${ }^{6}$ The presence of a pleocytosis on CSF and improvement following immunotherapy in our patient points toward a complex interplay of autoimmunity, genetic predisposition, and neurodegeneration. Furthermore, recent evidence exploring the mechanisms of action of IgLON5 in rat hippocampal neurons suggests that antibodies decreased cell surface IgLON5 clusters with internalization of antibody not reversed once the IgLON5 antibodies were removed from the media. ${ }^{7}$ This suggests a pathogenic role of these antibodies in the disease and raises the possibility of a treatable phase of the disease possibly in the early stages.

From the Department of Neurology (M.B., A.J., M.A.E., S.A.), and Department of Neurophysiology (S.J.), The Walton Centre NHS Foundation Trust; and Department of Respiratory and Sleep Medicine (E.B., R.P.), Aintree University Hospital NHS Foundation Trust, Liverpool, United Kingdom.

Author contributions: M.B.-primary author and looked after the patient. A.J., M.A.E., E.B., and R.P.—contributed to the manuscript and involved in patient's treatment. S.J.-contributed to the manuscript and neurophysiologist facilitating sleep studies. S.A.-lead consultant looking after the patient and contributor to the manuscript.
Acknowledgment: The authors thank Edward Jackson and the staff in the Neurosciences Laboratories with the help processing and providing the immunofluorescence results.

Study funding: No targeted funding reported.

Disclosure: M. Bonello reports no disclosures. A. Jacob serves on the scientific advisory board for Shire Pharmaceuticals; received speaker honoraria from Biogen Idec, Shire, and Terumo BCT; consulted for Shire Pharmaceuticals; and received research support from Biogen, Alexion, Shire, NHS, and University of Liverpool. M.A. Ellul received research support from the Association of British Neurologists. E. Barker, R. Parker, and S. Jefferson report no disclosures. S. Alusi received travel funding from Boston Scientific. Go to Neurology.org/nn for full disclosure forms. The Article Processing Charge was funded by the authors.

This is an open access article distributed under the terms of the Creative Commons Attribution-NonCommercial-NoDerivatives License 4.0 (CC BY-NC-ND), which permits downloading and sharing the work provided it is properly cited. The work cannot be changed in any way or used commercially without permission from the journal.

Received March 13, 2017. Accepted in final form June 2, 2017.

Correspondence to Dr. Bonello: Michael.bonello@thewaltoncentre. nhs.uk

1. Haitao R, Yingmai Y, Yan H, et al. Chorea and parkinsonism associated with autoantibodies to IgLON5 and responsive to immunotherapy. J Neuroimmunol 2016; 300:9-10.

2. Sabater L, Gaig C, Gelpi E, et al. A novel non-rapid-eye movement and rapid-eye-movement parasomnia with sleep breathing disorder associated with antibodies to IgLON5: a case series, characterisation of the antigen, and postmortem study. Lancet Neurol 2014;13:575-586.

3. Hogl B, Heidbreder A, Santamaria J, Graus F, Poewe W. IgLON5 autoimmunity and abnormal behaviours during sleep. Lancet 2015;385:1590.

4. Simabukuro MM, Sabater L, Adoni T, et al. Sleep disorder, chorea, and dementia associated with IgLON5 antibodies. Neurol Neuroimmunol Neuroinflamm 2015;2:e136.

5. Sanz R, Ferraro GB, Fournier AE. IgLON cell adhesion molecules are shed from the cell surface of cortical neurons to promote neuronal growth. J Biol Chem 2015;290: 4330-4342.

6. Gelpi E, Hoftberger R, Graus F, et al. Neuropathological criteria of anti-IgLON5-related tauopathy. Acta Neuropathol 2016;132:531-543.

7. Sabater L, Planaguma J, Dalmau J, Graus F. Cellular investigations with human antibodies associated with the anti-IgLON5 syndrome. J Neuroinflammation 2016;13:226. 


\section{Neurology \\ Neuroimmunology \& Neuroinflammation}

IgLON5 disease responsive to immunotherapy

Michael Bonello, Anu Jacob, Mark A. Ellul, et al.

Neurol Neuroimmunol Neuroinflamm 2017;4;

DOI 10.1212/NXI.0000000000000383

This information is current as of August 7, 2017

Neurol Neuroimmunol Neuroinflamm is an official journal of the American Academy of Neurology.

Published since April 2014, it is an open-access, online-only, continuous publication journal. Copyright

Copyright $\odot 2017$ The Author(s). Published by Wolters Kluwer Health, Inc. on behalf of the American

Academy of Neurology. All rights reserved. Online ISSN: 2332-7812.

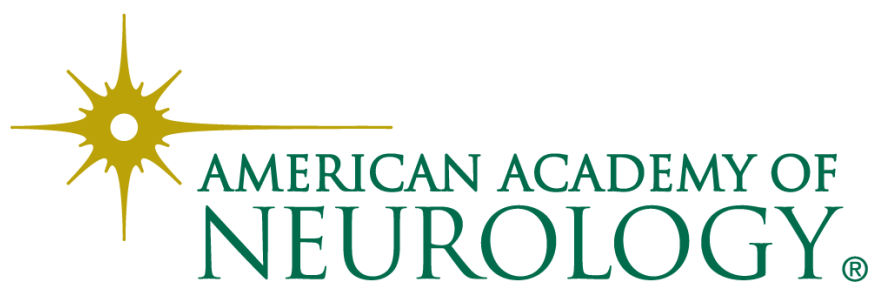




\section{Updated Information \& Services}

\section{Supplementary Material}

References

Subspecialty Collections

Permissions \& Licensing

Reprints including high resolution figures, can be found at: http://nn.neurology.org/content/4/5/e383.full.html

Supplementary material can be found at: http://nn.neurology.org/content/suppl/2017/08/07/4.5.e383.DC1 http://nn.neurology.org/content/suppl/2017/08/07/4.5.e383.DC2

This article cites 7 articles, 1 of which you can access for free at: http://nn.neurology.org/content/4/5/e383.full.html\#\#ref-list-1

This article, along with others on similar topics, appears in the following collection(s):

All Clinical Neurology

http://nn.neurology.org//cgi/collection/all_clinical_neurology

All Sleep Disorders

http://nn.neurology.org//cgi/collection/all_sleep_disorders

Autoimmune diseases

http://nn.neurology.org//cgi/collection/autoimmune_diseases

Encephalitis

http://nn.neurology.org//cgi/collection/encephalitis

Information about reproducing this article in parts (figures,tables) or in its entirety can be found online at:

http://nn.neurology.org/misc/about.xhtml\#permissions

Information about ordering reprints can be found online: http://nn.neurology.org/misc/addir.xhtml\#reprintsus

Neurol Neuroimmunol Neuroinflamm is an official journal of the American Academy of Neurology.

Published since April 2014, it is an open-access, online-only, continuous publication journal. Copyright

Copyright $\odot 2017$ The Author(s). Published by Wolters Kluwer Health, Inc. on behalf of the American Academy of Neurology. All rights reserved. Online ISSN: 2332-7812.

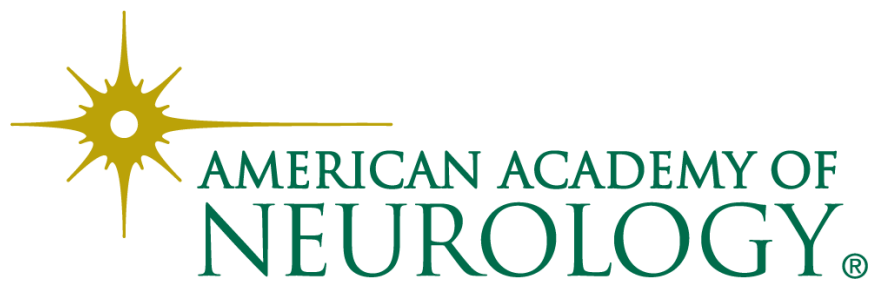

